\title{
POSTURAL ALTERATIONS IN CHILDREN WITH MOUTH BREATHING ASSESSED BY COMPUTERIZED BIOPHOTOGRAMMETRY
}

\author{
ALTERAÇÕES POSTURAIS EM CRIANÇAS PORTADORAS DE SINDROME DA \\ RESPIRAÇ̃̃O BUCAL, AVALIADAS ATRAVÉS DO MÉTODO DA \\ BIOFOTOGRAMETRIA COMPUTADORIZADA
}

Luciane Capelasso de Oliveira LIMA ${ }^{1}$, Mario Antônio BARAÚNA ${ }^{2}$, Maria José Junho SOLOGUREM ${ }^{3}$, Roberto Sérgio de Tavares CANTO ${ }^{4}$, Ada Clarisse GASTALDI ${ }^{5}$

\author{
1- MSc in Cardiorespiratory Physiotherapy. \\ 2- PhD in Human Motricity. Assistant Professor of the MSc course in Physioterapy. Cordinator of the Research Center of the Centro Universitário \\ do Triângulo (UNIT). Study Supervisor. \\ 3- Associate Professor in Pediatrics, UNIRIO. Professor of the MSc course in Physioterapy, UNIT. \\ 4- PhD in Medicine. Assitant Professor of the MSc course in Physiotherapy, UNIT. \\ 5- PhD in Rehabilitation. Assitant Professor of the MSc course in Physiotherapy, UNIT
}

Corresponding address: Luciane Capelasso de Oliveira LIMA - Rua Isau Anzai 152, Residencial Damha I, Presidente Prudente - SP, CEP 19053-360, Telephones: +55 (18) 231-8222, 231-8226, 9601-6070. Email: executivo@tvfronteira.com.br

Received: December 03, 2002 - Returned for modification: August 13, 2003 - Accepted: April 26, 2004

\begin{abstract}
Q

bjective: To determine and compare the posture of children with obstructive (OMB) and functional mouth breathing (FMB) and children with nasal breathing (NB) using computerized biophotogrammetry, as well as to determine the viability and efficacy of this method. Methods: Evaluative and personalized methods were used for the capture and analysis of angle images obtained from 19 NB, 26 FMB and 17 OMB children of either gender aged 8 to 10 years on anterior, posterior and profile views. The nonparametric Kruskal-Wallis test was applied to analyze the three groups as a whole and the Mann-Whitney test was used for pairwise comparison of the groups $(\mathrm{p}=0.05)$. Results: The angle related to the lateral knee condyle, lateral ankle malleolus and $5^{\text {th }}$ metatarsal diaphysis (KAM) was significantly greater in NB than in FMB children. With respect to the angle related to the nasal external acoustic meatus and pogonion (GMM), nasal external acoustic meatus and manubrium (GME), and $2^{\text {nd }}$ cervical vertebra, major cervical curvature point and $7^{\text {th }}$ cervical vertebra (C2C7), significantly higher values were observed for the OMB group compared to NB children. The angle formed by the $2^{\text {nd }}$ thoracic vertebra, the major prominent thoracic point and the $9^{\text {th }}$ thoracic vertebra (T2T9) was significantly greater in FMB than in OMB children. Conclusions: Computerized biophotogrammetry was found to e a safe and reliable technique, allowing comparison between the children analyzed, as well as the detection of postural alterations in mouth breathing children. Uniterms: Postural alterations; Mouth breathing; Children; Computerized biophotogrammetry.
\end{abstract}

\footnotetext{
RESUMO

bjetivos: Mensurar e comparar a postura de crianças respiradoras bucais obstrutivas (RBO) e funcionais (RBF), entre si e com crianças respiradoras nasais (RN), através da biofotogrametria computadorizada e verificar a viabilidade e a eficácia da utilização deste método. Métodos: Utilizaram-se métodos avaliativos e personalizados de captação e análise das imagens angulares de 19 crianças RN, 26 RBF e 17 RBO, de 8 a 10 anos de idade, de ambos os sexos, em face anterior, perfil e posterior. Resultados: Para análise dos resultados, aplicou-se o teste não-paramétrico de Kruskal-Wallis e de Mann-Whitney ( $\mathrm{p}=0,05)$. Observou-se que a angulação obtida relativa ao côndilo lateral do joelho, maléolo lateral do tornozelo e diáfise do $5^{\circ}$ metatarso (JTM), os resultados dos RN foram significativamente maiores do que os RBF. Quanto às angulações relativas à glabela, meato acústico esterno e mento (GMM), glabela, meato acústico esterno e manúbrio do esterno (GME) e 2 ${ }^{\mathrm{a}}$ vértebra cervical, local de maior curvatura cervical e $7^{\mathrm{a}}$ cervical (C2C7), os resultados dos RBO foram significativamente maiores do que os RN. Na angulação relativa à $2^{\mathrm{a}}$ vértebra torácica, local de maior proeminência torácica e $9^{a}$ torácica (T2T9), os resultados dos RN foram significativamente maiores do que os RBO. Na angulação de C2C7, os resultados dos RBO foram significantemente maiores do que os RBF, e na medida relativa a T2T9, os resultados dos RBF foram significativamente maiores do que os RBO. Conclusão: A técnica da biofotogrametria computadorizada revelou-se ser segura e fidedigna, permitindo a mensuração e comparação dos valores obtidos entre as crianças analisadas, assim como a verificação da deteç̧ão de alterações posturais nos respiradores bucais .

Unitermos: Alterações posturais; Síndrome da respiração bucal; Crianças; Biofotogrametria computadorizada.
} 


\section{INTRODUCTION}

Due to nasal obstruction and deleterious habits acquired early in life, as well as the failure to learn breathing throughby the natural route, i.e., the nose, individuals with mouth breathing live for a long time with a forward head posture to facilitate the entry of air through the mouth (Bianchini ${ }^{7}$ ). Aggravation of this inadequate position can lead to the development of permanent changes, including postural alterations, as one of the complications of this syndrome $\left(\right.$ Krakauer $^{19}$ ).

The present studyinvestigation is justified because it analyzesby the fact that it studies the set of problems associated with mouth breathing, identifies the morphological and myofunctional structures affected, and determines the performance of the best clinical practice, assessment and treatment. In this respect, physiotherapy acts asa physiotherapist acts as a member of the interdisciplinary team, allowing the establishment of preventive measures in terms ofagainst the impairment and consequences of erroneous breathing.

The objective of the present study was to determine and compare the posture of children with obstructive (OMB) and functional mouth breathing (FMB) in relation to nasal breathing (NB) children using computerized biophotogrammetry in order to verify the viability and efficacy of this method in the detection of postural alterations in individuals with mouth breathing.

\section{METHODS}

For establishment of the inclusion criteria and data collection, 166 questionnaires to be answered by the parents were distributed to $2^{\text {nd }}$ to $4^{\text {th }}$ grade children from schools in the city of Maringa, State of Parana, Brazil, which contained the following information: personal data, personal and family history, home and social environment, socioeconomic assessment, social and affective relationships, and questions regarding signs and symptoms resulting from mouth breathing. For inclusion in the study, the children should present at least three of the following signs and symptoms indicative of mouth breathing and determined on the basis of the questionnaire: running nose, repeated infection of the upper airways with or without antibiotic therapy, nasal obstruction, sneezing, itchy nose, eyes and ears, frequent coughing, repeated pneumonia, asthma, frequent vomiting, lack of air, shortness of breath, frequent choking, anorexia, agitated sleep, low weight gain and small stature, snoring, irritability, staying with the mouth open, and headaches. Forty-nine children referred to the Integrated Center for the Mouth Breather (CIRB), Maringa, Parana, were selected. The children were assessed by their pediatricians for diagnosis of mouth breathing, with differential diagnosis of obstructive and functional mouth breathing. Obstructive mouth breathing is characterized by mechanical obstacles, including nasal, retronasal and oral obstacles clinically and radiographically diagnosed.
Examples are adenoid and tonsil hypertrophy, septal deviation, nasal stenosis, nasal polyps, nasal abscesses and tumors, among others. Patients with functional mouth breathing include those already submitted to adenoidectomy as well as tonsillectomy, but who continue to breathe through the mouth, although the upper respiratory tract is absolutely permeable. These patients have repetitive cataractphlegm manifestations characteristic of allergic rhinitis $\left(\right.$ Carvalho $\left.^{9}\right)$.

Using the same questionnaire, 19 children aged 8 to 10 years without any symptoms were selected to constitute the control group.

The following exclusion criteria were established $\left(\right.$ Carvalho $^{9}$, Baraúna $^{2}$, Bricot $^{8}$, Tribastone ${ }^{28}$ ): limb shortening, important visual alterations, sequelae of lower limb fractures, sequelae of poliomyelitis, neuropraxias, alterations in plantar impression, pé torto congenito ou pé equino, congenital clubfoot or equinovarus, progressive muscular dystrophy, generalized muscle weakness, and neural mouth breathing. Based on these exclusion criteria, the examiners selected 62 children of both genders aged 8 to 10 years, who were divided into the following groups: OMB group - 17 children, FMB group - 26 children, and NB group -19 children. Children participated in the study after an informed consent form was signed by the caretaker.

The children, barefooted and with adequate clothing, were palpated always by the same examiner and the reference anatomical points were marked with adhesive tape and reflexive cylinders for digitization of the points that form angles based on the intersection of two lines according to the method of Deloroso ${ }^{11}$. The anatomical points established for analysis of the postural angles inon the anterior,lateral and posterior view and profile views by computerized biophotogrammetry are shown in Figure 1. Data were collected using the anatomical points cited by Wenzel, et al. $^{30}$, Huggare and Kylamarkula ${ }^{15}$, Kylamarkula and Huggare $^{18}$, Farah and Tanaka ${ }^{12}$, and Tribastone ${ }^{28}$.

After delineation, the children were orthostatically positioned in the three aforementioned positions in a previously established and demarcated place, with the feet dispostos com as pontas divergentes a 36 graus de aberturatheir feet arranged with their tips diverging with a 36-degree opening according to the angle of Piok, cited by Baraúna $^{2}$ and Tribastone ${ }^{28}$.

Computed biophotogrammetry is an evaluative and personalized method that was used for capture and analysis of the angle images. In this method, a Panasonic VHSC Palmcorder camera was positioned at a 3-m distance parallel and perpendicularly to the child to be filmed. The camera was fixed to a three-legged legged support at a $0.75 \mathrm{~m}$ height from the floor, properly centralized, leveled and perpendicular. The same apparatus, previously positioned, was always employed for maintenance of the same distances and heights. The recorded images were transferred onto the monitor of a 133-MHz Pentium computer equipped witha image- an imageacquiring Pixel View card and then analyzed with the ALCIMAGEM 2, 2000 program for angle quantification (Baraúna and Adorno ${ }^{3}$, Baraúna, et al. ${ }^{4}$, Barreto ${ }^{5}$ ). 
For statistical analysis, the nonparametric Kruskal-Wallis test was applied to analyze the three groups as a whole and the Mann-Whitney test was used for pairwise comparison of the groups $(p=0.05)$

\section{RESULTS}

The results obtained after statistical analysis are shown in Table 1.

\section{DISCUSSION}

Biophotogrammetry is a method currently used method which permits measurement ofto measure body angles based on photographs and, through connection to a computer, renders the data obtained highly reliable. The results obtained in the present study with this technique agree with those reported by various investigators, butshow divergences to those obtaineddiffer from those reported by others.

In this respect, no significant difference was observed between the three groups regarding lateral deviation of the spine at the GMCP point in the anterior view and at points C7T12L5 and TT in the posterior view, in contrast to the findings of Sá Filho ${ }^{24}$ and Carvalho ${ }^{10}$. It is known that there is no connection in muscle triggering from the forward projection of the head in an attempt to breathe, which could cause lateral deviation of the spine, a fact notdemonstrated yet. The studies mentioned above are descriptive and were only based on the observation of clinical signs, in contrast to the present investigation, the findings of which are based on measurements and comparisons between groups.

No significant alteration was observed at the RCPCH and LCPCH points measured to determine horizontalization of the collarbone. This finding disagrees with those reported by Sá Filho ${ }^{24}$, who stated that individuals with mouth breathing present a barrel or inspiratory chest, in which the collarbones are horizontalized, a condition commonly observed in asthmatic patients (Marcondes, Sustovich, $\operatorname{Ramos}^{22}$ ). The present study is also descriptive and supported by observations, thus leaving doubts as to the existence of these alterations. The existence of thoracic alterations in individuals with mouth breathing resulting from the horizontalization of the collarbone, as observed in the present experimental study, cannot be confirmed since they are more dependent of the severity of this syndrome and complications during asthmatic episodes (Carvalho ${ }^{9}$, Kimmelman $^{17}$, Marney Jr${ }^{23}$, Stokes and Della Mattia ${ }^{26}$ ) caused by the disease.

Further observation of changes in the structure of the ribcage and diaphragmatic dynamics showed no significant alterations in Charpy's angle. This finding disagrees with those reported by Aragão ${ }^{1}$ and Carvalho ${ }^{10}$. The present study agrees with the findings of Sá Filho ${ }^{24}$ who found different types of thoracic alterations in individuals with mouth breathing. It is also believed that an altered Charpy's angle might be related to a decrease in respiratory resistance during the change from nasal to mouth breathing, reducing the use of the diaphragmatic musculature, causing costal respiration and, consequently, a reduction in this angle. In addition, an inspiratory pattern, as a complication of the increased lower airway resistance, might favor the development of marked thoracic deformities, with elevation of the last ribs due to shortening of the diaphragm and an increase in this angle. In view of the numerous thoracic changes demonstrable by both an increased and reduced Charpy's angle, no single type of thoracic alterations and diaphragmatic behavior can be characterized in children with mouth breathing through the measurement of this angle, as presently shown.

In an attempt to determine alterations in the protrusion of the shoulder and position of the scapula, SIST9 angles
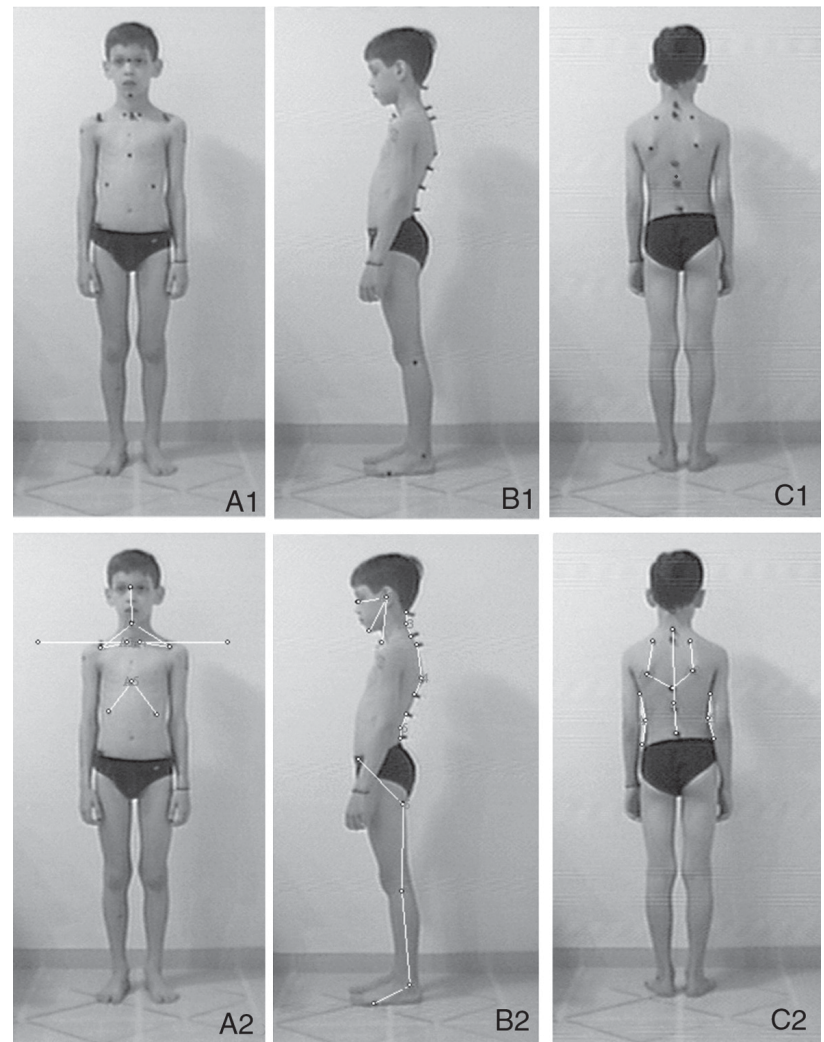

FIGURE 1- Delineated anatomical points analyzed. A1, A2 Anterior: $(1,2)$ right and left glabella, mentum and coracoid process (RGMCP and LGMCP, respectively); $(3,4)$ coracoid process, condylar angle and right and left horizontal (RCPCH and $\mathrm{LCPCH}$, respectively); (5) Charpy's angle (CA). B1, B2 - Profile: (1) glabella, external acoustic meatus and mentum (GMM); (2) glabella, external acoustic meatus and manubrium sterni (GMS); (3) C2, point of greatest cervical curvature and C7 (C2C7); (4) T2, point of greatest thoracic prominence and T9 (T2T9); (5) L1, point of greatest lumbar curvature and L5 (L1L5); (6) anterior superior iliac spine, gluteal line and lateral condyle of the knee (SGLK); (7) gluteal line, lateral condyle of the knee and lateral malleolus of the ankle (GLKA); (8) lateral condyle of the knee, lateral malleolus of the ankle and 5th metatarsal diaphysis (KAM). C1, C2 - Posterior: (1) vertebral line C7, T12 and L5 (C7T12L5); (2,3) right (RTT) and left (LTT) talus triangle; $(4,5)$ right and left superior scapular angle, inferior scapular angle and T9 (RSIST9 and LSIST9, respectively). 
were measured in posterior view with no significant difference between groups. The present study disagrees with the reports of Sá Filho ${ }^{24}$, Aragão ${ }^{1}$ and Carvalho ${ }^{10}$. Protrusion of the shoulders compresses the ribcage and impairs inspiratory expansion caused by traction of the infrahyoid musculature, but specifically of the omohyoid muscle, the inferior belly of which is inserted in the upper border of the scapula. This causes imbalance in the middle trapezius, serratus major and rhomboid muscles, whose hypotonic-hypotrophic state reduces the fixation of the scapula to the chest, as well as hypertonicity of the antagonistic (pectoral) muscles. According to Tribastone ${ }^{28}$, the scapulo-humeral cinturabelt is a very mobile anatomical complex and the aladaswinged scapulae can be classified into two different types, abducted and adducted aladaswinged scapulae, depending on the musculature affected as a result of body compensation offor the degree of alteration. Due to the different postural compensations found in children with mouth breathing and because the level of severity of these alterations involves a different musclestructure,structure, no single type of scapular alteration resulting from internal rotation of the shoulder can be inferred, as found in the present study.

Comparison of the three groups revealed significant postural alterations at the GMM, GMS, C2C7 and T2T9 angles. In addition, separate comparison of the FMB and OMB groups also showed differences in postural changes between the two groups. Different results were reported by Aragão $^{1}$, Bianchini ${ }^{7}$, Gazolla ${ }^{13}$, Krakauer $^{19}$, Kumar, et al ${ }^{20}$ and Marchesan and Krakauer ${ }^{21}$, who did not differentiate the two types of mouth breathing in terms of posture. The results of the present study agrees with those reported by Behlfelt, et al. ${ }^{6}$ and Huggare and Kylamarkula ${ }^{15}$, who analyzed only children with obstructive mouth breathing, differentiating them from functional mouth breathing children. The results obtained based on concrete and reliable measurements confirm that FMB and OMB children do not present the same postural alterations and should therefore be treated differently.

Comparison of the results obtained in the profile view between OMB and FMB children did not reveal a significant difference in GMM and GMS angles, with the two groups showing both chin retraction and forward projection of the head. The same was observed when comparing the NB and FMB groups, but a small return of the forward projection of the head was noted in the FMB group. These data are in agreement with those reported by Wenzel, et $\mathrm{al}^{30}$. Forward projection of the head causes changes in the tension of the

TABLE 1- Mean body angles (degrees) obtained for children with obstructive (OMB) and functional mouth breathing (FMB) and children with nasal breathing (NB) analyzed by the Kruskal-Wallis and Mann-Whitney tests

\begin{tabular}{|c|c|c|c|c|}
\hline \multirow[t]{2}{*}{ Body angle } & \multirow{2}{*}{$\begin{array}{l}\begin{array}{l}\text { Kruskal-Wallis } \\
\text { probability }\end{array} \\
\mathrm{NB} \times \mathrm{OMB} \times \mathrm{FMB}\end{array}$} & \multicolumn{3}{|c|}{$\begin{array}{l}\text { Mann-Whitney } \\
\text { probability }\end{array}$} \\
\hline & & $\mathrm{NB} \times \mathrm{FMB}$ & $\mathrm{NB} \times \mathrm{OMB}$ & $\mathrm{FMB} \times \mathrm{OMB}$ \\
\hline RGMCP & 0.1743 & 0.5804 & 0.1986 & 0.0693 \\
\hline LGMCP & 0.1535 & 0.8628 & 0.1198 & 0.0692 \\
\hline $\mathrm{RCPCH}$ & 0.3748 & 0.2686 & 0.8116 & 0.2225 \\
\hline $\mathrm{LCPCH}$ & 0.9201 & 0.6369 & 0.8612 & 0.9901 \\
\hline $\mathrm{CA}$ & 0.7165 & 0.4826 & 0.4849 & 0.8521 \\
\hline C7T12L5 & 0.2565 & 0.0911 & 0.3077 & 0.7839 \\
\hline RTT & 0.9297 & 0.7386 & 0.7874 & 0.8422 \\
\hline LTT & 0.3542 & 0.9633 & 0.1443 & 0.2629 \\
\hline RSIST9 & 0.9342 & 0.7649 & 0.7754 & 0.8327 \\
\hline LSIST9 & 0.7989 & 0.5969 & 0.9116 & 0.5591 \\
\hline GMM & $0.0083^{*}$ & 0.1775 & $0.0014^{*}$ & 0.0692 \\
\hline GMS & $0.0081^{*}$ & 0.0530 & $0.0036^{*}$ & 0.0926 \\
\hline $\mathrm{C} 2 \mathrm{C} 7$ & $0.0022^{*}$ & 0.3062 & $0.0004^{*}$ & $0.0148^{*}$ \\
\hline Т2Т9 & $0.0030^{\star}$ & 0.6789 & $0.0009 *$ & $0.0073^{*}$ \\
\hline L1L5 & 0.4608 & 0.7826 & 0.4751 & 0.1876 \\
\hline SGLK & 0.5064 & 0.2684 & 0.7388 & 0.4469 \\
\hline GLKA & 0.5930 & 0.6619 & 0.4363 & 0.3635 \\
\hline KAM & 0.0540 & $0.0199 *$ & 0.1428 & 0.3375 \\
\hline
\end{tabular}

(*) Significantly different at the 0.05 level. 
lingual, facial, especially buccinator, and supra-and infrahyoid muscles, which contract the superior constrictor muscle of the pharynx, rectifying the oronasopharyngeal space and facilitating the entry of air through the mouth. Removal of the obstruction in FMB children leads to a reduction in strength of the entire, contractedthe effort of the entire tense musculature and to a partial decrease in postural alterations through a moderate, although not complete, return of the forward projection of the head.

Comparison of the GMS angle revealed significant alterations in the forward projection of the head in the OMB group. Similar results have been reported by Aragão ${ }^{1}$, Joseph $^{16}$, Marchesan and Krakauer ${ }^{21}$ and Tourn ${ }^{27}$. However, the first two studies did not describehow the type of alteration of the headwas and all four reports were only descriptive. Our results agree with the cephalometric study of Behlfelt, et $\mathrm{al}^{6}$. The applicative advantage of the present method compared to cephalometry is that biophotogrammetry is a noninvasive procedure which also reliably shows this forward alteration of the head.

Comparison of the GMM angle measured to analyze retraction of the chin showed significant alterations in the OMB group, in agreement with the studies of Bianchini ${ }^{7}$, Hellsing and L'estrange ${ }^{14}$ and Joseph ${ }^{16}$. Forward projection of the head probably causes contraction/tension mainly of the supra- and infrahyoid musculature, which lower and retrude the mandibular muscles and therefore are antagonists of the masticatory muscles, provoking tension of the orbicular muscle of the mouth during its action of lip sealing resulting from mandibular retraction. The present results show that, in addition to the measurement of the gonial angle based on the cephalometric analysis of Bimler $\left(G_{a z o l l a}{ }^{13}\right)$, noninvasive biophotogrammetry allows the determination of mandibular retraction, confirming changes in facial muscle structures which can become definitive, including bone involvement and deformation, if the cause of mouth breathing is not reversed.

In contrast to Sá Filho ${ }^{24}$, significant alterations were also observed in cervical straightening at the C2C7 angle in the OMB group. Similar results have been reported in studies showing involvement of the neck musculature, but that did not specify the postural alterations of the head adopted (Aragão $^{1}$, Bianchini ${ }^{7}$, Marchesan and Krakauer $^{21}$ ). On the other hand, an extended position of the head during mouth breathing has also been observed by Kumar, et al. ${ }^{20}$. With respect to the altered cervical curvature, our results agree with Kylarmarkula and Huggare ${ }^{18}$ and Huggare and Kylarmarkula ${ }^{15}$. One explanation for the extension of the head might be the insertions of the posterior suprahyoid, stylohyoid and posterior digastric musculature, with their origins in the mastoid process of the temporal bone, which are tense due to their contraction mediated by lowering of the hyoid bone in the forward projection of the head.

The postural alterations triggered significant changes in the T2T9 angle, indicating altered thoracic convexity in the OMB group. The present study agrees with those of Sá Filho $^{24}$, Carvalho ${ }^{10}$ and Souchard ${ }^{25}$. Direct alterations in the mandible are mediated by the genioglossus muscle, while indirect changes are mediated by the hyoid bone and by the geniohyoid and mylohyoid muscles. Changes in the cervical spine are mediated by the superior and middle constrictor muscles of the pharynx, while alterations in the skull and posterior muscle chains are triggered by the styloglossus, stylohyoid and palatoglossus muscles. With respect to protraction of the head, shortening of the posterior muscle chain, particularly of the suboccipital muscles, is associated with shortening of the sternocleidomastoid and scalene muscles, which in turn is associated with the cervicalthoracic-abdominal-pelvic fascia. These functional muscle alterations favor an increase in thoracic convexity, an inspiratory position of the chest and medial rotation of the shoulders, thus demonstrating postural decompensation resulting from respiratory obstruction in individuals with mouth breathing.

Regarding the L1L5 angle indicating alterations in lumbar curvature, SGLK referring to the bascule of the hip and GLKA indicating knee flexion-extension, no significant alterations were observed in any of the groups. These results disagree with those reported by Carvalho ${ }^{10}$, Sá Filho ${ }^{24}$ and Farah and Tanaka ${ }^{12}$. The absence of alterations in the present study might be due to the fact that the children used two types of postural compensation, i.e., anteriorization and pelvic antepulsion, demonstrating the importance of individual assessment since each child assumes a different position triggered by gravity.

Significant alterations were also observed in the tibiotarsal flexion angle of FMB children. In this respect, our study agrees with the results reported by Farah and Tanaka ${ }^{12}$ for children with nasal breathing and by Valentino and Melito ${ }^{29}$ who, in an electromyographic study, also found a functional relationship between masticatory muscles and certain muscles of the leg after creating an interdental occlusal dysfunction. It should be noted that the only alteration observed in FMB children was a tibiotarsal flexion probably as a way of postural compensation in order to maintain correct balance of the body structures.

\section{CONCLUSION}

Computerized biophotogrammetry was found to be a safe and reliable method for body angle measurements obtained to determine and compare the posture of children with obstructive and functional mouth breathing and those with nasal breathing. In addition, it was possible to determine the efficacy of this technique in the detection of postural alterations in these children with mouth breathing. 


\section{REFERENCES}

1- Aragão W. Aragao’s function regulation, the stomatognatic system and postural changes in children. J Clin Pediatr Dent 1991;15:22630 .

2- Baraúna MA. Estudo comparativo entre a avaliação do equilíbrio estático de indivíduos amputados de coxa e não amputados. Lisboa; 1997. [Tese de Doutorado em Motricidade Humana - Universidade Técnica de Lisboa - Portugal].

3- Baraúna MA, Adorno MLGR. Avaliação cinesiológica das curvaturas lombar e torácica das gestantes através do cifolordômetro e da fotogrametria computadorizada e sua correlação com a dor lombar. Fisioter Bras 2001;2(3):145-55.

4- Baraúna MA, Canto RST, Oliveira AS, Soares AB, Silva CDC, Cardoso FAG. Avaliação do equilíbrio estático do portador de diabetes mellitus pela biofotogrametria. Diabetes Clin 2002;7(1):57-62.

5- Barreto RR. Avaliação da postura corporal de indivíduos portadores de deficiência visual, através da biofotogrametria computadorizada. Uberlândia - MG; 2003. [Dissertação de Mestrado em Fisioterapia UNIT, Centro Universitário do Triângulo].

6- Behlfelt K, Linder-Aronson S, Neander P. Posture of head, the hyoid bone, and the tongue in children with and without enlarged tonsils. Eur J Orthod 1990;12:458-67.

7- Bianchini EMG. A cefalometria nas alterações miofuncionais orais: diagnóstico e tratamento fonoaudiológico. Carapicuíba; 1998. PróFono Departamento Editorial.

8- Bricot B. Posturologia. São Paulo: Ícone; 1999. p.11-365.

9- Carvalho GD. Síndrome do respirador bucal ou insuficiente respirador nasal. Revista Secretários de Saúde 1996 jul 1;2(18):22-4.

10- Carvalho GD. S.O.S. respirador bucal, obstáculos nas diferentes estruturas, dificultando ou impedindo o livre processo respiratório. Centro de Estudo Avançado Odontofono, Poços de Caldas: 1999. p. $1-5$.

11- Deloroso MGB. Estudo comparativo entre a avaliação do tórax de crianças asmáticas e não asmáticas, através do cálculo do ângulo de Charpy pela fotogrametria computadorizada. Uberlândia - MG; 1999. [Dissertação de Mestrado em Fisioterapia - UNIT, Centro Universitário do Triângulo].

12- Farah EA, Tanaka C. Postura e mobilidade da coluna cervical e do tronco em portadores de alterações miofuncionais orais. Rev Assoc Paul Cir Dent 1997;51:171-5.

13- Gazolla SM. Ênfase ao órgão fonoarticulatorio: língua, em relação às aparatologias Bimler e Klammt. Presidente Prudente - SP 1997. [Monografia de Pós-Graduação em Ortopedia dos Maxilares UNOESTE, Universidade do Oeste Paulista].

14- Hellsing E, L'estrange P. Changes in lip pressure following extention and flexion of the head and at changed mode of breathing. Am J Orthod Dentofacial Orthop 1987;91:286-4.

15- Huggare J, Kylämarkula S. Morfhology of the first cervical vertebra in children with enlarged adenoids. Eur J Orthod 1985;7:936.

16- Joseph R. The effect al airway interference on the growth and development of the face, jaws, and dentition. In J Orofacial Myology 1982;8:4-9.

17- Kimmelman CP. The problem of nasal obstruction. Otolaryngol Clin North Am 1989;22(2):253-64.
18- Kylämarkula S, Huggare J. Head posture and the morphology of the first cervical vertebra. Eur J Orthod 1985;7:151-6.

19- Krakauer LRH. Relação entre respiração bucal e alterações posturais em crianças: uma análise descritiva. Rev Soc Bras Fonoaudiol 1998;2(1):18-25.

20- Kumar R, Sidhu SS, Karbanda O, Tandon DA. Hyoid bone and atlas vertebra in established mouth breathers: a cephalometric study. J Clin Pediatr Dent 1995;19:191-4.

21- Marchesan IQ, Krakauer LH. A importância do trabalho respiratório na terapia miofuncional. Tópicos em Fonoaudiologia. São Paulo: Lovise; 1995. p.155-60.

22- Marcondes M, Sustovich RD, Ramos LR. Clínica médica: propedêutica e fisiopatologia. Rio de Janeiro: Guanabara Koogan; 1984. p. 20.

23- Marney Jr SR. Pathophisiology of reactive airway disease and sinusitis. Annals of Otologis, Rhinology and Laryngology. Saint Louis 1996;105:98-100

24- Sá Filho FPG. As bases fisiológicas da ortopedia maxilar. São Paulo: Santos; 1994. p.81-4.

25- Souchard PE. Reeducação postural global. São Paulo: Ícone; 1986.

26- Stokes N, Della Mattia D. A student research review of the mouth breathing habit: discussing measurement methods, manifestation and treatment of the mouth breathing habit. Probe 1996;30(6):212-4.

27- Tourn LP. The long face syndrome and impairment of the nasopharyngeal airway. Angle Orthod 1990; 60:167-76.

28- Tribastone F. Tratado de exercícios corretivos, aplicados à reeducação motora postural. Barueri -SP: Manole; 2001. p. 1-366.

29- Valentino B, Mellito F. Functional relationships between the muscles of mastigation and the muscles of the leg. Surgical Radiology Anatomy 1991;13:33-7.

30- Wenzel AD, Henriksen J, Meisen BD. Nasal respiratory resistance and head posture: effect of intranasal corticosteroid (Budesonide) in children with asthma and perennial rhinitis. Am J Orthod 1983; 84:422-6. 